\title{
Effect of SARS and COVID-19 outbreaks on urology practice and training
}

\author{
CH Yee *, HF Wong, Mandy HM Tam, Steffi KK Yuen, HC Chan, MH Cheung, Alan TO Yu, Y Chiu, \\ NH Chan, LH Leung, Ada TL Ng, Denathan MC Law, TL Ng, Jeremy YC Teoh, Peter KF Chiu, CF Ng
}

\section{A B S T R A C T}

Introduction: The objective was to investigate the changes in urology practice during coronavirus disease 2019 (COVID-19) pandemic with a perspective from our experience with severe acute respiratory syndrome (SARS) in 2003.

Methods: Institutional data from all urology centres in the Hong Kong public sector during the COVID-19 pandemic (1 Feb 2020-31 Mar 2020) and a non-COVID-19 control period (1 Feb 201931 Mar 2019) were acquired. An online anonymous questionnaire was used to gauge the impact of COVID-19 on resident training. The clinical output of tertiary centres was compared with data from the SARS period.

Results: The numbers of operating sessions, clinic attendance, cystoscopy sessions, prostate biopsy, and shockwave lithotripsy sessions were reduced by $40.5 \%, 28.5 \%, 49.6 \%, 44.8 \%$, and $38.5 \%$, respectively, across all the centres reviewed. The mean numbers of operating sessions before and during the COVID-19 pandemic were $85.1 \pm 30.3$ and $50.6 \pm 25.7$, respectively $(\mathrm{P}=0.005)$. All centres gave priority to cancer-related surgeries. Benign prostatic hyperplasia-related surgery (39.1\%) and ureteric stone surgery (25.5\%) were the most commonly delayed surgeries. The degree of reduction in urology services was less than that during SARS $(47.2 \%, 55.3 \%$, and $70.5 \%$ for operating sessions, cystoscopy, and biopsy, performed by residents before and during the COVID-19 pandemic were $75.4 \pm 48.0$ and $34.9 \pm 17.2$, respectively $(\mathrm{P}=0.002)$.

This article was published on $26 \mathrm{Feb}$ 2021 at www.hkmj.org.

Conclusion: A comprehensive review of urology respectively). The mean numbers of operations

changes in every aspect of practice.

\section{Hong Kong Med J 2021;27:258-65}

https://doi.org/10.12809/hkmj208822

${ }_{1,2} \mathrm{CH}$ Yee *, MB, BS, FRCS (Urol)

1,2 HF Wong, MB, ChB

${ }^{1,3}$ MHM Tam, MB, ChB, FRCS (Urol)

${ }_{1,4}$ SKK Yuen, MB, BS, FRCS (Urol)

${ }^{5} \mathrm{HC}$ Chan, MB, ChB, FRCS (Urol)

${ }^{6}$ MH Cheung, MB, ChB, FRCS (Urol)

${ }^{7,8}$ ATO Yu, MB, BS, FRCS (Urol)

${ }^{9}$ Y Chiu, MB, ChB, FRCS (Urol)

${ }^{10} \mathrm{NH}$ Chan, MB, ChB, FRCS (Urol)

${ }^{11}$ LH Leung, MB, ChB, FRCS (Urol)

${ }^{12,13}$ ATL Ng, MB, BS, FRCS (Urol)

${ }^{14}$ DMC Law, MB, BS, FRCS (Urol)

${ }^{15} \mathrm{TL} \mathrm{Ng}, \mathrm{MB}, \mathrm{BS}$, FRCS (Urol)

1,2 JYC Teoh, MB, BS, FRCS (Urol)

1,2 PKF Chiu, MB, ChB, FRCS (Urol)

${ }_{1,2}$ CF Ng, MB, ChB, FRCS (Urol)

SH Ho Urology Centre, Department of Surgery, The Chinese University of Hong Kong, Hong Kong

2 Department of Surgery, Prince of Wales Hospital, Shatin, Hong Kong

${ }^{3}$ Department of Surgery, Alice Ho Miu Ling Nethersole Hospital, Hong Kong

${ }^{4}$ Department of Surgery, North District Hospital, Hong Kong

${ }^{5}$ Department of Surgery, United Christian Hospital, Hong Kong

${ }^{6}$ Department of Surgery, Tseung Kwan O Hospital, Hong Kong

${ }^{7}$ Department of Surgery, Tuen Mun Hospital, Hong Kong

${ }^{8}$ Department of Surgery, Pok Oi Hospital, Hong Kong

${ }^{9}$ Department of Surgery, Princess Margaret Hospital, Hong Kong

${ }^{10}$ Department of Surgery, Pamela Youde Nethersole Eastern Hospital, Hong Kong

${ }^{11}$ Department of Surgery, Kwong Wah Hospital, Hong Kong

${ }^{12}$ Department of Surgery, Queen Mary Hospital, Hong Kong

${ }^{13}$ Department of Surgery, Tung Wah Hospital, Hong Kong

${ }^{14}$ Department of Surgery, Caritas Medical Centre, Hong Kong

${ }^{15}$ Department of Surgery, Queen Elizabeth Hospital, Hong Kong

practice during the COVID-19 pandemic revealed * Corresponding author: yeechihang@surgery.cuhk.edu.hk

New knowledge added by this study

- As in other parts of the world, the impact of coronavirus disease 2019 on urology affected all key aspects of service. However, the degree of impact was less than that during the severe acute respiratory syndrome epidemic.

- Urology training was affected by the dramatic reduction in the number of surgeries performed for benign prostatic hyperplasia and urolithiasis.

Implications for clinical practice or policy

- A prompt infection control response on the hospital level and heightened public awareness of personal hygiene have reduced the risk of infection among medical personnel to a minimal level.

- A prioritisation policy of surgeries and services by malignancy alone during pandemics is worth reconsideration. More detailed differentiation of the urgency of interventions is needed to cover the whole spectrum of diseases, from benign to malignant. 


\section{Introduction}

In November 2002, there were reports of severe pneumonia of unknown aetiology in Guangdong Province in Southern China, which totalled more than 300 cases by February 2003. ${ }^{1}$ The disease was spread to Hong Kong in February 2003 through a visitor from southern China, eventually leading to hospital and community outbreaks. ${ }^{2}$ The World Health Organization (WHO) named the condition severe acute respiratory syndrome (SARS) and issued a global alert and instituted worldwide surveillance on 13 March $2003 .{ }^{3}$ A novel coronavirus (SARS-CoV) was identified as the causative agent. ${ }^{4}$ The epidemic reached its peak in Hong Kong at the end of March 2003, when the disease was spread to the community, and it was eventually brought under control in May 2003. By the end of the epidemic in July 2003, 8096 cases had been reported in 29 countries and regions, with a death toll of $774(9.6 \%){ }^{5}$

Seventeen years later, a coronavirus took the world by surprise again. At the end of 2019, a cluster of patients with pneumonia of unidentified cause were reported in Wuhan, China. ${ }^{6}$ The first case of similar pneumonia of unknown aetiology outside China was reported in Thailand on 13 January 2020, and subsequently, the disease struck Hong Kong on 23 January 2020. The novel virus is designated as severe acute respiratory syndrome coronavirus-2 (SARS-CoV-2), and the standard name of coronavirus disease 2019 (COVID-19) was announced by the WHO to correspond to the pneumonia caused by this novel coronavirus. On 30 January 2020, the WHO declared a 'public health emergency of international concern', and later, on 11 March 2020, COVID-19 was characterised by the WHO as a pandemic. ${ }^{7}$

The impact of COVID-19 affected the whole spectrum of clinical practice, just like it has affected every corner of the world. Although urology does not stand at the forefront of care for patients with COVID-19, every practising urologist has been affected by the global outbreak. Hong Kong is in the unique position of having dealt with two serious coronavirus outbreaks in two decades. The invaluable lessons learnt from SARS in 2003 can help the urology community to face COVID-19 in 2020. The current study aimed to review the territory-wide urology practice in Hong Kong during SARS and COVID-19 from the perspectives of both practising urologists and urology residents in training.

\section{Methods}

Hong Kong's healthcare system is divided into a government-run service and a private sector. The public sector dominates secondary and tertiary care, accounting for approximately $80 \%$ of all hospital admissions, $90 \%$ of total bed-days, and $100 \%$ of

\section{嚴重急性呼吸系統綜合症和2019冠狀病毒病 大流行對泌尿科醫生臨床實踐和培訓的影響}

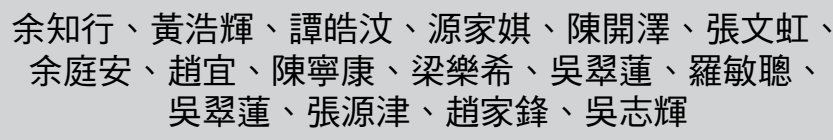

引言：根據2003年嚴重急性呼吸系統綜合症（SARS）的經驗, 檢視 2019 冠狀病毒病（COVID-19）大流行期間對泌尿科醫生臨床實踐的 影響。

方法: 獲取香港公立醫院所有泌尿科於COVID-19大流行期間（2020 年2月1日至2020年3月31日）和前一年同期（2019年2月1日至2019 年3月31日）的機構數據、以線上匿名調查評估COVID-19對實習醫生 培訓的影響, 以及以一所大學教學醫院的臨床產量與SARS 時期的數 據作比較。

結果 : 在所有檢查的中心中, 手術次數、門診就診次數、膀胱鏡檢查 次數、前列腺活檢次數和衝擊波碎石術次數分別減少 $40.5 \%$. $28.5 \%$ 、 $49.6 \% 、 44.8 \%$ 和 $38.5 \%$ 。平均手術次數由COVID-19大流行前的 $85.1 \pm 30.3$ 減至COVID-19大流行期間的50.6 $25.7 （ \mathrm{P}=0.005 ）$ 所有中心都優先考慮進行與癌症相關的手術。良性前列腺增生相 關手術 $(39.1 \%)$ 和輸尿管結石手術 $(25.5 \%)$ 是最常見的延遲手 術。COVID-19大流行期間泌尿科服務的減少幅度較SARS 期間為低 (後者的手術、膀胱鏡檢查和活檢數量分別減少 $47.2 \%$ 、 $55.3 \%$ 和 $70.5 \%$ ）。實習醫生的平均手術次數由 COVID-19大流行之前的 75.4 4 48.0減至COVID-19大流行期間的34.9 $\pm 17.2 （ \mathrm{P}=0.002 ）$

結論：研究顯示COVID-19大流行期間對泌尿科醫生各項臨床實踐造 成影響。

professional training for doctors. ${ }^{8}$ The current study focused on a comprehensive review of urology practice in Hong Kong's public sector.

This study was approved by the ethics committee of our institution. All 11 urology units in the public sector were included in the review (Table 1). For ease of interpretation, two hospitals were sometimes grouped as a single unit when they provide a comprehensive urology service together. Four areas were investigated to assess the impact of COVID-19 in the urology community: (1) new urology practice strategies introduced; (2) new infection control measures for urologists; (3) training and academic activities; and (4) crossspecialty deployment from urology teams to support COVID-19 frontline staff. With regard to new urology practice strategies and new infection control measures, five aspects of urology services were individually studied: (1) surgery; (2) out-patient clinics; (3) endoscopy; (4) prostate biopsy; and (5) shockwave lithotripsy (SWL).

After COVID-19 spread to Hong Kong at the end of January, the number of new cases rose steadily. A brief surge was observed in March 2020 due to an increase of imported cases before travel restrictions were implemented. ${ }^{9}$ Urology service data from 1 February 2020 to 31 March 2020 were collected from all centres in the public sector to investigate 
TABLE I. Urology centres in Hong Kong

\begin{tabular}{|c|c|c|c|c|c|}
\hline & $\begin{array}{c}\text { Catchment } \\
\text { area population }\end{array}$ & $\begin{array}{l}\text { No. of } \\
\text { urologists }\end{array}$ & $\begin{array}{l}\text { No. of urology } \\
\text { residents }\end{array}$ & $\begin{array}{c}\text { Deployment } \\
\text { mechanism installed }^{*}\end{array}$ & $\begin{array}{c}\text { Deployment } \\
\text { mechanism activated† }\end{array}$ \\
\hline $\mathrm{PWH}$ & 1414000 & 7 & 3 & No & Not applicable \\
\hline $\mathrm{NDH}+\mathrm{AHNH}$ & & 7 & 1 & Yes & No \\
\hline $\mathrm{QMH}+\mathrm{TWH}$ & 513700 & 5 & 3 & No & Not applicable \\
\hline $\mathrm{UCH}$ & 1181200 & 3 & 5 & Yes & Yes \\
\hline $\mathrm{TKOH}$ & & 2 & 1 & Yes & No \\
\hline $\mathrm{TMH}+\mathrm{POH}$ & 1203500 & 8 & 3 & No & Not applicable \\
\hline PMH & 2040900 & 7 & 6 & Yes & No \\
\hline CMC & & 3 & 2 & Yes & No \\
\hline PYNEH & 746200 & 4 & 4 & Yes & No \\
\hline $\mathrm{KWH}+\mathrm{OLMH}$ & 562000 & 4 & 3 & No & Not applicable \\
\hline $\mathrm{QEH}$ & & 8 & 2 & Yes & No \\
\hline
\end{tabular}

Abbreviations: $\mathrm{AHNH}=$ Alice Ho Miu Ling Nethersole Hospital; CMC = Caritas Medical Centre; COVID-19 = coronavirus disease 2019; KWH = Kwong Wah Hospital; NDH = North District Hospital; OLMH = Our Lady of Maryknoll Hospital; PMH = Princess Margret Hospital; $\mathrm{POH}=$ Pok Oi Hospital; PWH = Prince of Wales Hospital; PYNEH = Pamela Youde Nethersole Eastern Hospital; $\mathrm{QEH}=$ Queen Elizabeth Hospital; QMH = Queen Mary Hospital;TKOH = Tseung Kwan O Hospital;TMH = Tuen Mun Hospital; TWH = Tung Wah Hospital; UCH = United Christian Hospital

* Deployment of urology team members to support other departments during the COVID-19 pandemic

+ Whether any members of the urology team had already been deployed to other departments as of I April 2020

the impact of COVID-19 on the four previously mentioned areas of urology practice and training. Similar data from 1 February 2019 to 31 March 2019 were captured as a control for comparison. Furthermore, an anonymous online questionnaire was sent to all urology residents to gauge the impact of COVID-19 on training in detail.

The Prince of Wales Hospital was at the forefront of the SARS outbreak in Hong Kong in $2003 .^{2}$ The Hospital's urology service during SARS (ie, 1 March 2003-30 April 2003) was reviewed using institutional data. A control period from 1 March 2004 to 30 April 2004 was adopted for comparison against the urology practice during SARS. Descriptive statistics were used to characterise the demographic data. Continuous variables were described as means, and categorical variables were described as frequencies. Means were compared using $t$ tests with statistical significance set at 5\%. The SPSS software package (Windows version 22.0; IBM Corp, Armonk [NY], United States) was used for analysis.

\section{Results}

The review covered 11 urology units encompassing the urology practice of 15 hospitals in Hong Kong that serve a population of 7.5 million (Table 1). ${ }^{10}$ All of the investigated urology units have reduced their numbers of operating sessions (Fig 1). The first hospital began to reduce surgeries on 27 January 2020 , only 4 days after the first COVID-19 case was confirmed in Hong Kong. Across all urology units, the mean numbers of operating sessions before the COVID-19 pandemic (1 Feb 2019-31 March 2019 ) and during the COVID-19 pandemic (1 Feb 2020-31 March 2020) were 85.1 \pm 30.3 and 50.6 \pm 25.7 , respectively $(\mathrm{P}=0.005)$. All urology units have given priority to cancer or cancer-related surgeries. The most commonly delayed type of surgery during the COVID-19 pandemic was benign prostatic hyperplasia-related surgery, accounting for $39.1 \%$ of all delayed cases, followed by ureteric stone surgery (25.5\%). In addition, all living-related transplant surgeries were suspended during the COVID-19 pandemic period.

All five aspects of urology services have been reduced in the territory (Fig 2). The numbers of operating sessions, clinic attendance, cystoscopy sessions, prostate biopsies, and SWL cases were reduced by $40.5 \%, 28.5 \%, 49.6 \%, 44.8 \%$, and $38.5 \%$, respectively across all of the reviewed centres.

Table 2 summarises the practice changes in the urology units. These included special attention to patients with TOCC (travel, occupation, contact, and cluster history) risk of COVID-19 infection. These patients were either deferred in their hospital attendance or were assessed by a dedicated group of medical personnel so as to achieve efficient use of personal protective equipment (PPE). Teleconsultation was available in one of the centres for urologists to carry out clinical consultations with TOCC-positive patients. Most urologists executed their clinical duties wearing regular surgical masks. Only one urology centre used N95 respirators in 


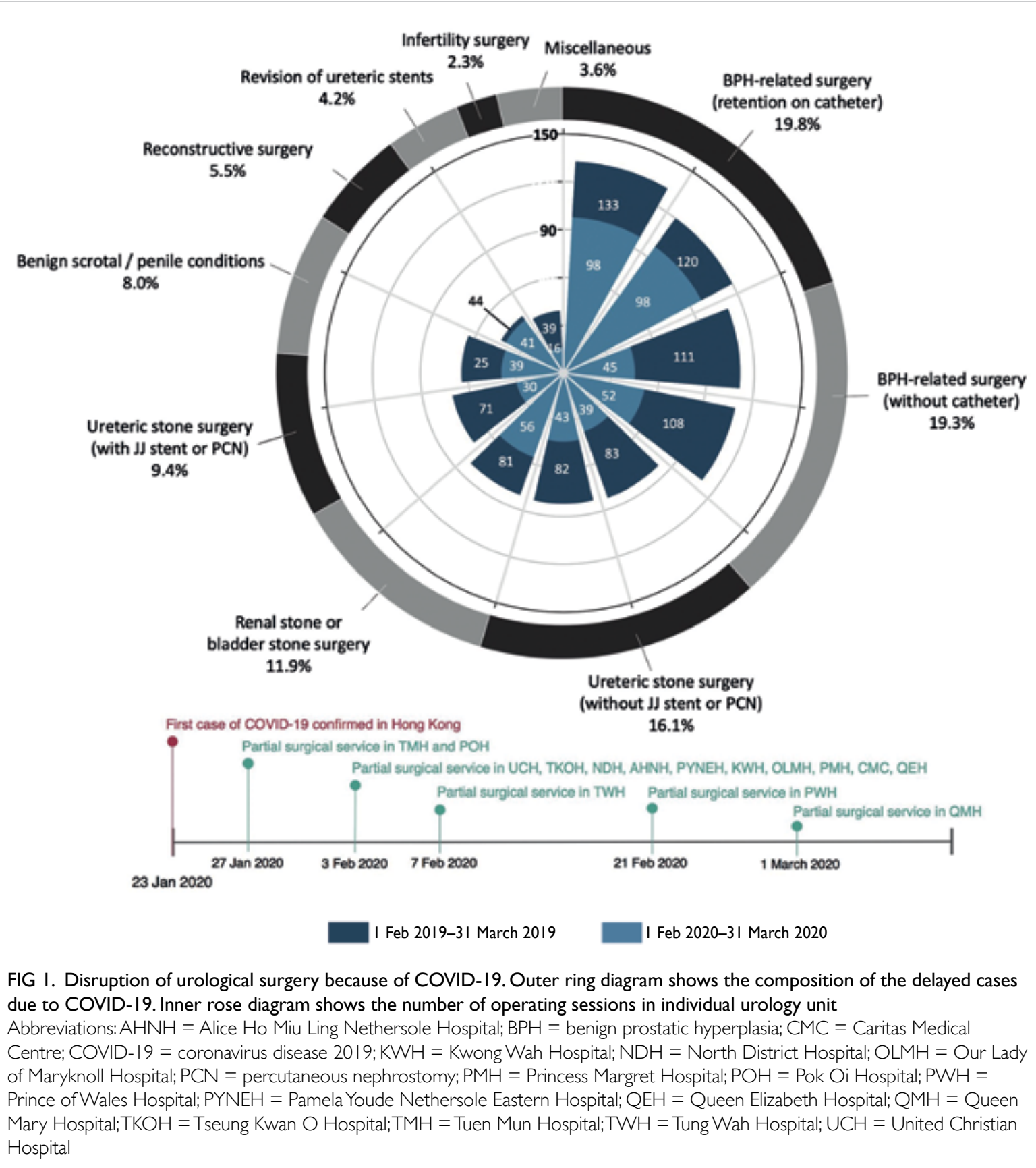

clinical practice, specifically for prostate biopsy.

A comparison of urology services in Prince of Wales Hospital between the COVID-19 pandemic in 2020 and the SARS period in 2003 is shown in Figure 3 . There was less reduction in all aspects during COVID-19 than during SARS (operating sessions: $30.9 \%$ vs $47.2 \%$; cystoscopy: $27.7 \%$ vs $55.3 \%$; prostate biopsy: $47.6 \%$ vs $70.5 \%$; SWL: $13.9 \%$ vs $23.6 \%)$. The percentage reductions of different urology services during the COVID-19 pandemic in Prince of Wales Hospital were all less than those during the SARS period in 2003. The absolute urology output during SARS actually exceeded that during the 2004 non-
SARS normal time in some areas, including flexible cystoscopy and SWL cases.

Training and academic activities were heavily affected by the COVID-19 pandemic (online supplementary Appendix). The survey of urology residents yielded a response rate of $48.5 \%$ (16/33). Surgical exposure was significantly hampered, and $53.3 \%$ of the respondents had their professional examinations cancelled because of COVID-19, resulting in delays in their acquisition of professional qualifications. Three out of the 11 centres reported having switched some of their academic meetings to online platforms. 


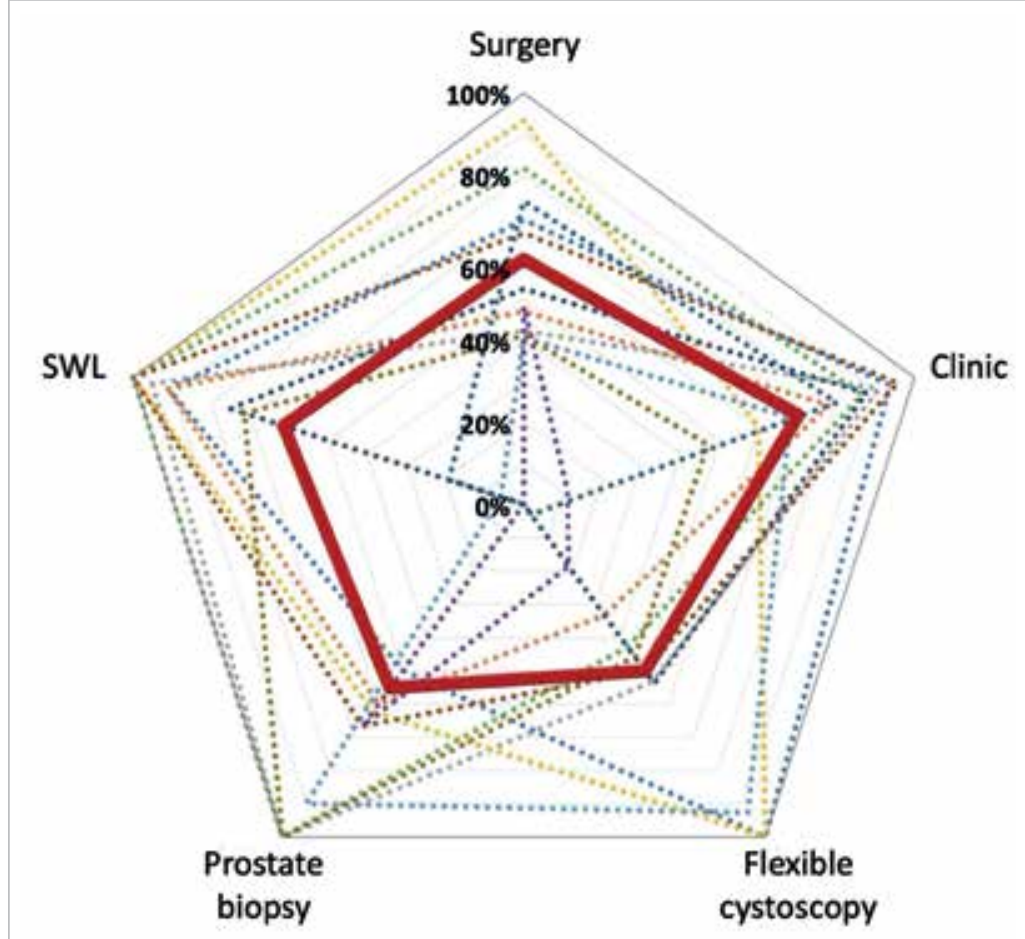

FIG 2. Percentage of urological services maintained during the COVID-19 pandemic as compared with 2019

Colour dotted lines: Percentage of service retained in individual urology centre

Red solid line: Overall percentage of service retained in all urology centres

Service reference period: COVID- 19 period (I Feb 2020-3I March 2020) versus nonCOVID-19 period (I Feb 2019-3। March 2019)

Abbreviations: COVID-19 = coronavirus disease 2019; SWL = shockwave lithotripsy
2 to $20 \mathrm{ng} / \mathrm{mL}$. When its usage is more widely accepted by the urology community in practice, it could provide useful guidance in prioritising patients for prostate biopsy when resources are limited.

Most centres in the study reserved operating sessions for cancer cases or complicated stones. This is largely in line with the recommendation of Stensland et $\mathrm{al}^{13}$, who suggested that uncomplicated endourology procedures, reconstructive surgeries, transplant surgeries, and andrological interventions be delayed. A similar perspective was endorsed by the European Association of Urology. ${ }^{14}$ Subcategorisation of urological cancer surgeries is necessary because of the wide spectrum of cancer behaviour within the specialty. ${ }^{13,14}$ Highgrade bladder cancer, advanced kidney cancer, and testicular cancer should take priority for operations, whereas most prostatectomies for prostate cancer should be delayed. In the current review, no differentiation was assigned to hospital policies of prioritising cancer surgery. Delays in interventions for other benign conditions could ultimately increase the risk of complications and unscheduled hospital admissions. Nevo et $\mathrm{al}^{15}$ reported that prolonged stent dwelling time was a risk factor for postoperative sepsis. Prospective assessment is needed to evaluate our current surgery triage protocol.

There are still conflicting opinions regarding the risk of SARS-CoV-2 transmission during laparoscopic and robotic surgery. The SARS-CoV-2 virus can remain viable and infectious in aerosols for hours, ${ }^{16}$ but respiratory aerosol-generating procedures seem to have a higher viral content and thus pose a greater risk of transmission than surgical aerosol-generating procedures that aerosolise blood and tissue fluid. ${ }^{17}$ The EAU Robotic Urology Section recommended that laparoscopic and robotic surgeries proceed with the necessary precautions. ${ }^{18}$ In all of the centres reviewed in the study, laparoscopic and robotic surgeries were executed with conventional infection control protocols. Thus far, no COVID-19 cases have been reported to be transmitted via laparoscopic or robotic surgery.

With respect to the PPE used, regular use of face shields or goggles was not observed in most centres. Evidence so far has shown that besides the respiratory system, SARS-CoV-2 can infect the digestive system and the urinary system, causing the virus to be found in the stool and urine. ${ }^{19}$ Ling et $\mathrm{a}^{20}$ reported COVID-19 cases in which urine samples remained positive even after throat swabs had converted negative. A similar observation about stool was reported by Chen et $\mathrm{al}^{21}$ who found that $64.29 \%$ of patients tested positive for viral RNA in faeces after pharyngeal swabs turned negative. As asymptomatic COVID-19 patients have been reported, ${ }^{22}$ and contact with urine and stool during urological procedures is not uncommon, the 
TABLE 2. Changes to urology practice in response to the COVID-19 pandemic

\begin{tabular}{|c|c|c|c|}
\hline Urology service & $\begin{array}{l}\text { Responses to } \\
\text { COVID-19 }\end{array}$ & Practice change & $\begin{array}{l}\text { Units adopting } \\
\text { the practice }\end{array}$ \\
\hline \multirow[t]{12}{*}{ Surgery } & \multirow[t]{11}{*}{$\begin{array}{l}\text { New modifications to } \\
\text { clinical system }\end{array}$} & $\begin{array}{l}\text { 1. Reduction of available elective operation sessions } \\
\text { 2. Delaying elective operations except cases in the following categories: }\end{array}$ & $100 \%$ \\
\hline & & a. Confirmed cancer cases & $100 \%$ \\
\hline & & b. Suspected cancer cases & $100 \%$ \\
\hline & & c. Ureteric stones with or without ureteric stent/nephrostomy tube & $72.7 \%$ \\
\hline & & $\begin{array}{l}\text { d. Benign prostatic obstruction for which weaning off urethral catheter has } \\
\text { failed }\end{array}$ & $18.2 \%$ \\
\hline & & e. Tenckhoff catheter insertion & $18.2 \%$ \\
\hline & & 3. Increased preference for SA to GA as the anaesthetic mode & $63.6 \%$ \\
\hline & & 4. Testing selected TOCC-negative patients' COVID-19 status & $45.5 \%$ \\
\hline & & 5. Delaying elective operations if patients are TOCC-positive & $36.4 \%$ \\
\hline & & & $27.3 \%$ \\
\hline & & 7. Cancelling all local anaesthetic operations & $27.3 \%$ \\
\hline & $\begin{array}{l}\text { Additional infection } \\
\text { control precautions }\end{array}$ & $\begin{array}{l}\text { 1. Using face shields or goggles } \\
\text { 2. Minimising the number of surgeons in the operating theatre }\end{array}$ & $\begin{array}{l}36.4 \% \\
27.3 \%\end{array}$ \\
\hline \multirow[t]{5}{*}{ Clinic } & \multirow[t]{4}{*}{$\begin{array}{l}\text { New modifications to } \\
\text { clinical system }\end{array}$} & $\begin{array}{l}\text { 1. Allowing patients to come to the clinic and refill their prescriptions without } \\
\text { medical consultation to minimise their exposure in the hospital }\end{array}$ & $100 \%$ \\
\hline & & 2. Checking patients' body temperature and TOCC before they enter the clinic & $100 \%$ \\
\hline & & $\begin{array}{l}\text { 3. Delaying relatively non-urgent cases (voiding dysfunction, non-obstructive } \\
\text { stones, benign renal lesions, andrology cases, chronic pelvic pain syndrome) } \\
\text { to have follow-up after COVID-19 pandemic }\end{array}$ & $18.2 \%$ \\
\hline & & 4. Availability of teleconsultation room & $9.1 \%$ \\
\hline & $\begin{array}{l}\text { Additional infection } \\
\text { control precautions }\end{array}$ & 1. Wearing surgical masks during consultation & $100 \%$ \\
\hline \multirow[t]{6}{*}{ Flexible cystoscopy } & $\begin{array}{l}\text { New modifications to } \\
\text { clinical system }\end{array}$ & $\begin{array}{l}\text { 1. Reduction of available elective cystoscopy sessions } \\
\text { 2. Delaying elective cystoscopy cases, except cases in the following } \\
\text { categories: }\end{array}$ & $81.8 \%$ \\
\hline & & a. Microscopic haematuria & $72.7 \%$ \\
\hline & & b. Bladder cancer surveillance cystoscopy & $63.6 \%$ \\
\hline & & c. Suspected bladder stones & $63.6 \%$ \\
\hline & & d. Gross haematuria & \\
\hline & $\begin{array}{l}\text { Additional infection } \\
\text { control precautions }\end{array}$ & $\begin{array}{l}\text { 1. Changing PPE for each consecutive cystoscopy case } \\
\text { 2. Using face shields or goggles }\end{array}$ & $\begin{array}{l}18.2 \% \\
18.2 \%\end{array}$ \\
\hline \multirow[t]{8}{*}{ Prostate biopsy } & $\begin{array}{l}\text { New modifications to } \\
\text { clinical system }\end{array}$ & $\begin{array}{l}\text { 1. Reduction of available elective biopsy sessions } \\
\text { 2. Delaying the following cases until after the COVID-19 pandemic: }\end{array}$ & $63.6 \%$ \\
\hline & & a. PSA $<10 \mathrm{ng} / \mathrm{mL}$ & $45.5 \%$ \\
\hline & & b. PSA $<15 \mathrm{ng} / \mathrm{mL}$ & $18.2 \%$ \\
\hline & & c. $P S A<20 \mathrm{ng} / \mathrm{mL}$ & $27.3 \%$ \\
\hline & & d. Patients with prostate cancer on active surveillance & $36.4 \%$ \\
\hline & Additional infection & 1. Using face shields or goggles & $18.2 \%$ \\
\hline & control precautions & 2. Using N95 respirators & $9.1 \%$ \\
\hline & & 3. Changing PPE for each consecutive biopsy case & $9.1 \%$ \\
\hline \multirow[t]{3}{*}{ SWL } & New modifications to & 1. Delaying the following cases until after the COVID-19 pandemic: & \\
\hline & clinical system & a. Renal stones & $\begin{array}{l}81.8 \% \\
27.3 \%\end{array}$ \\
\hline & & $\begin{array}{l}\text { b. Ureteric stones with ureteric stent/nephrostomy tube } \\
\text { 2. Reduction of available elective SWL sessions }\end{array}$ & $\begin{array}{l}27.3 \% \\
27.3 \%\end{array}$ \\
\hline
\end{tabular}

Abbreviations: COVID-19 = coronavirus disease 2019; GA = general anaesthesia; PPE = personal protective equipment; PSA = prostate-specific antigen; SA = spinal anaesthesia; SWL = shockwave lithotripsy;TOCC = travel, occupation, contact, and cluster history

optimal standard of PPE for urologists needs further consideration.

We observe that the surveyed residents' training and academic activities were affected by the current pandemic. Furthermore, there may be a preference for surgical interventions to be performed by more experienced surgeons so as to reduce the operating time. ${ }^{23}$ In addition, most of the delayed cases during this COVID-19 pandemic were endourology cases (Fig 1), which account for the main bulk of urology resident training materials. A similar observation was echoed by urology residents in Italy. ${ }^{24}$

The outbreak of SARS in 2003 marked a critical turning point in Hong Kong. Invaluable lessons were learnt, including improvements in infection control measures and more rapid response. The public has perceived face masks as a tool for preventing infection both during the SARS outbreak and in the post-SARS era. ${ }^{25}$ Lau et $\mathrm{al}^{26}$ 


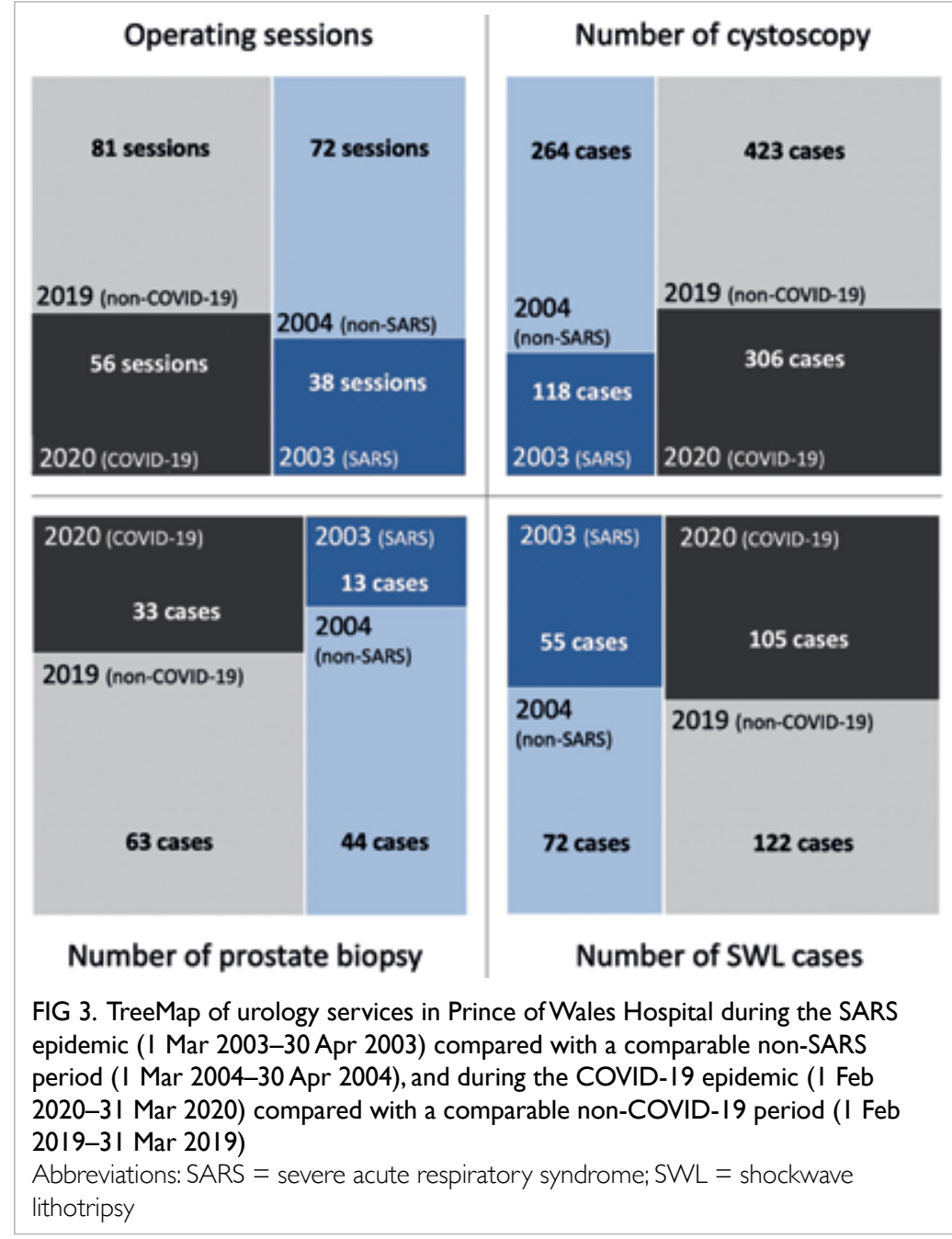

reported that $70.7 \%$ of the respondents to a survey in Hong Kong would frequently wear masks, $67.3 \%$ would avoid going to hospitals, and $71.5 \%$ would avoid going to crowded places if a few new SARS cases were reported. Further, healthcare workers have developed good infection control habits (eg, hand hygiene precautions and appropriate PPE selection). ${ }^{8}$ These elements all contributed to the multi-faceted strategies of different institutions urology departments when they were confronted by COVID-19 in 2020. The current study revealed that measures to minimise the infection risk were adopted in the very early phase of COVID-19 emergence. All of the investigated urology centres have reorganised their services to decrease patient flow and reduce the risk of mass gathering. Together with the heightened public awareness of personal hygiene, these factors could assist with containment of infection. Taking Prince of Wales Hospital as an example, the clinical output of minimal services during the COVID-19 pandemic was still higher than that in 2004 during the post-SARS period. This pattern is expected to be similar in other major urology centres in Hong Kong considering the growth in population and service need. However, no hospital outbreaks of COVID-19 have been observed so far in Hong Kong, unlike during SARS, and unlike a number of centres in other parts of the world during COVID-19. The experience of SARS in Hong Kong might have inadvertently prepared medical personnel across all specialties in our locality to face this COVID-19 pandemic with a more timely and comprehensive reaction.

A limitation of our study is that we did not investigate behaviour in the private sector. However, the public sector accounts for about $70 \%$ of hospitalbased services provided in Hong Kong, ${ }^{27}$ and thus, it is reasonable to interpret the current study as a meaningful representation of urology practice across the whole city during the COVID-19 pandemic.

\section{Conclusion}

Our study on urology practice reviewed the impact of COVID-19 from a metropolitan-city-wide perspective. The unique experience of the SARS outbreak in 2003 prepared Hong Kong in an unusual way to face the current pandemic of COVID-19. Changes to every aspect of urology practice were observed. Rapid responses from surgical teams in concert with the efforts from different specialties in the medical field have minimised the risk of outbreaks in hospitals and institutions. Prospective studies are needed to review the outcomes of these changes to urology practice.

\section{Author contributions}

$\mathrm{CH}$ Yee and CF Ng contributed to the concept of the study. $\mathrm{CH}$ Yee contributed to the analysis and interpretation of data, and drafting of the manuscript. All authors contributed to the acquisition of data and critical revision for important intellectual content. All authors had full access to the data, contributed to the study, approved the final version for publication, and take responsibility for its accuracy and integrity.

\section{Conflicts of interest}

As editors of the journal, JYC Teoh and CF Ng were not involved in the peer review process. Other authors have disclosed no conflicts of interest.

\section{Funding/support}

This research received no specific grant from any funding agency in the public, commercial, or not-for-profit sectors.

\section{Ethics approval}

The study was approved by the ethics committee of our institution's Survey and Behavioural Research Ethics board (Ref SBRE-19-563).

\section{References}

1. Zhong NS, Zheng BJ, Li YM, et al. Epidemiology and cause of severe acute respiratory syndrome (SARS) in Guangdong, People's Republic of China, in February, 2003. 
Lancet 2003;362:1353-8.

2. Tomlinson B, Cockram C. SARS: experience at Prince of Wales Hospital, Hong Kong. Lancet 2003;361:1486-7.

3. Tsang KW, Ho PL, Ooi GC, et al. A cluster of cases of severe acute respiratory syndrome in Hong Kong. N Engl J Med 2003;348:1977-85.

4. Peiris JS, Yuen KY, Osterhaus AD, Stöhr K. The severe acute respiratory syndrome. N Engl J Med 2003;349:243141.

5. Hui DS. Severe acute respiratory syndrome (SARS): lessons learnt in Hong Kong. J Thorac Dis 2013;5 Suppl 2:S122-6.

6. Li Q, Guan X, Wu P, et al. Early transmission dynamics in Wuhan, China, of novel coronavirus-infected pneumonia. N Engl J Med 2020;382:1199-207.

7. World Health Organization. WHO director-general's opening remarks at the media briefing on COVID-1911 March 2020. Available from: https://www.who.int/ $\mathrm{dg} /$ speeches/detail/who-director-general-s-openingremarks-at-the-media-briefing-on-covid-19-.-11march-2020. Accessed 17 Apr 2020.

8. Food and Health Bureau, Hong Kong SAR Government. Report of the strategic review on healthcare manpower planning and professional development. Available from: https://www.fhb.gov.hk/en/press_and_publications/ otherinfo/180500_sr/srreport.html. Accessed 17 Apr 2020.

9. Centre for Health Protection, Hong Kong SAR Government. Coronavirus disease (COVID-19) in HK. Available from: https://chp-dashboard.geodata.gov.hk/ covid-19/en.html. Accessed 17 Apr 2020.

10. Census and Statistics Department, Hong Kong SAR Government. Population. Available from: https://www. censtatd.gov.hk/hkstat/sub/so20.jsp. Accessed $17 \mathrm{Apr}$ 2020.

11. Ranney ML, Griffeth V, Jha AK. Critical supply shortagesthe need for ventilators and personal protective equipment during the COVID-19 pandemic. $N$ Engl J Med 2020;382:e41.

12. Chiu PK, Ng CF, Semjonow A, et al. A multicentre evaluation of the role of the prostate health index (PHI) in regions with differing prevalence of prostate cancer: adjustment of PHI reference ranges is needed for European and Asian settings. Eur Urol 2019;75:558-61.

13. Stensland KD, Morgan TM, Moinzadeh A, et al. Considerations in the triage of urologic surgeries during the COVID-19 pandemic. Eur Urol 2020;77:663-6.

14. Ribal MJ, Cornford P, Briganti A, et al. European Association of Urology Guidelines Office Rapid Reaction Group: an organisation-wide collaborative effort to adapt the European Association of Urology Guidelines recommendations to the coronavirus disease 2019 era. Eur Urol 2020;78:21-8.

15. Nevo A, Mano R, Baniel J, Lifshitz DA. Ureteric stent dwelling time: a risk factor for post-ureteroscopy sepsis. BJU Int 2017;120:117-22.

16. van Doremalen N, Bushmaker T, Morris DH, et al. Aerosol and surface stability of SARS-CoV-2 as compared with SARS-CoV-1. N Engl J Med 2020;382:1564-7.

17. Cook TM. Personal protective equipment during the coronavirus disease (COVID) 2019 pandemic-a narrative review. Anaesthesia 2020;75:920-7.

18. Mottrie A. EAU Robotic Urology Section (ERUS) guidelines during COVID-19 emergency. Available from: https://uroweb.org/eau-robotic-urology-section-erusguidelines-during-covid-19-emergency/. Accessed $17 \mathrm{Apr}$ 2020

19. Ozma MA, Maroufi P, Khodadadi E, et al. Clinical manifestation, diagnosis, prevention and control of SARSCoV-2 (COVID-19) during the outbreak period. Infez Med 2020;28:53-65.

20. Ling $Y, X u$ SB, Lin YX, et al. Persistence and clearance of viral RNA in 2019 novel coronavirus disease rehabilitation patients. Chin Med J (Engl) 2020;133:1039-43.

21. Chen Y, Chen L, Deng Q, et al. The presence of SARSCoV-2 RNA in feces of COVID-19 patients. J Med Virol 2020;92:833-40.

22. Bai Y, Yao L, Wei T, et al. Presumed asymptomatic carrier transmission of COVID-19. JAMA 2020;323:1406-7.

23. Porpiglia F, Checcucci E, Amparore D, et al. Slowdown of urology residents' learning curve during COVID-19 emergency. BJU Int 2020;125:E15-7.

24. Amparore D, Claps F, Cacciamani GE, et al. Impact of the COVID-19 pandemic on urology residency training in Italy. Minerva Urol Nefrol 2020;72:505-9.

25. Siu JY. Qualitative study on the shifting sociocultural meanings of the facemask in Hong Kong since the severe acute respiratory syndrome (SARS) outbreak: implications for infection control in the post-SARS era. Int J Equity Health 2016;15:73.

26. Lau JT, Yang X, Pang E, Tsui HY, Wong E, Wing YK. SARS-related perceptions in Hong Kong. Emerg Infect Dis 2005;11:417-24.

27. Census and Statistics Department, Hong Kong SAR Government. Thematic household survey report No. 63. December 2017. Available from: https://www.statistics. gov.hk/pub/B11302632017XXXXB0100.pdf. Accessed 10 Apr 2020 